\title{
The Emergence and Development of Specialist Courts: Lessons for Juvenile Justice from the History of the Children's Court in South Australia?
}

\author{
Daniel King ${ }^{1, *}$, Andrew Day ${ }^{2}$ and Paul Delfabbro ${ }^{1}$ \\ ${ }^{1}$ School of Psychology, Adelaide University, Australia; ${ }^{2}$ School of Psychology, Deakin University, Australia
}

\begin{abstract}
To illustrate how specialist courts have developed to manage juvenile offenders, this paper provides an overview of the history and development of the youth court in one jurisdiction, South Australia. Drawing on interviews conducted with judicial officers, the paper seeks to highlight some of the changes that have taken place since the Court's inception, as well as how the Court currently understands its role and positioning within the broader justice and welfare systems. Key discussion points of these interviews included the Youth Court's guiding principles and how they impact on court procedures and responses to young people in the system, as well as the challenges that limit, or create difficulties for, the effective operation of the Youth Court. It is concluded that the Youth Court system attempts to balance both welfare and justice approaches to dealing with young people, but are sometimes hindered by inadequate procedural, structural and resource-related factors - some of which exist externally to the Youth Court itself.
\end{abstract}

Keywords: Children's courts, juvenile justice, young offenders.

\section{INTRODUCTION}

These are interesting times for researchers and practitioners working within all areas of criminal justice. On the one hand, there is an impressive body of research testifying to the utility of a broad range of rehabilitative programs with individuals who have committed crimes (Andrews \& Bonta, 2010), while on the other, communities around the world appear to be more risk aversive and punitive in their attitudes toward offenders. As Ward, Day, and Casey (2006) suggest: "There appears to be a hardening of feelings and a determination...to make individuals pay severely for transgressions against the state and the community" (p.6). At the same time, and in contrast, recent years have seen the development and proliferation of a range of less punitive sentencing options and growing interest in how the law might be used in ways that promote therapeutic outcomes for offenders. The introduction and development of a range of new specialist courts and diversionary programs in Australian jurisdictions over the last ten years provides perhaps the strongest example of this (Polk, 2003), given that these initiatives aim to respond to the needs of offenders and the community in ways that are intended to directly address the problems that cause offending or to prevent offending from escalating (Berman \& Feinblatt, 2005). Specialist courts generally seek to apply principles of therapeutic jurisprudence in so far as they are based on the assumption that, for certain types of individuals, problem-solving responses are more appropriate than those which are based on either deterrence or punishment (Wexler, 2000; Winick, 2003).

*Address correspondence to this author at the School of Psychology, The University of Adelaide, Adelaide, SA, 5005, Australia; Tel: +61(8) 83033740; Fax: +61 88303 3770; E-mail: daniel.king@adelaide.edu.au
In Australia, specialist courts currently exist for offenders with substance use problems, with mental health problems, who identify as having Indigenous cultural backgrounds, and who perpetrate violence against women (Payne, 2006). By far the most established of the specialist courts, however, are those which exist for children and young people. Children's courts have existed for well over 100 years, but have experienced many changes over time. The aim of this paper is to provide an overview of the history and development of the Youth Court in one jurisdiction, South Australia, in order to illustrate how one particular type of specialist court has developed, and to highlight some of the changes that have taken place since the Court's inception. This paper draws on interviews conducted with judicial officers within the Youth Court system, and seeks to examine how the Court currently understands its role and positioning within the broader justice and welfare systems.

\section{History of the Youth Court in South Australia}

\section{THE FIRST CHILDREN'S COURT}

In 1869 , the first court for dealing solely with child offenders was established in the State of Massachusetts, USA. This specialist court was developed in response to the growing public movement towards 'child-saving'; a welfare philosophy concerned with the protection of minors from the full force of adult law (Dickey, 1987). At the time there was consensus that the judicial system should adopt a more sympathetic approach to its dealings with young people, as well as concerns about the stigmatizing effects on young people resulting from appearing in a police court, and the potential to encourage more serious offending through exposure to, and interaction with, serious adult offenders (Seymour, 1988b). 
The children courts in the State of Massachusetts attracted significant interest from various political and judicial bodies in the British colonies and, in 1885, a report published by the Way Commission in South Australia recommended the adoption of the methods developed in Massachusetts. This involved the introduction of new procedures as well as structural modifications to the existing court system. Specifically, the Way Commission recommended: (a) that all inquiries before justices into charges against juveniles be conducted at different times from other cases and that these inquiries should be held in a separate building; (b) that a parent be required to attend these proceedings; (c) an officer of the department responsible for the care of children be required to attend; and (d) that children who had been arrested were to be held in premises attached to the department, rather than in police cells. These recommendations were formally enacted in 1890 with the establishment of the first Australian Children's Court in the city of Adelaide, and have remained in place until the current day.

The original Children's Court was responsible for dealing with both neglected and abused children and young offenders. However, in its early stages, the court did not have legislation that was designed specifically for juveniles and had to rely on various minor amendments to existing legislation, and use innovative administration when necessary (Seymour, 1988b). For this reason (and despite the improvements offered by having a Children's Court) many young people were still not being afforded adequate protection from the severity and formality of adult courts. Thus, for many years following their establishment, juvenile courts in South Australia did not operate all that differently from the adult courts.

In the early 1900s, numerous concerned parties, including magistrates, policymakers, and social commentators, called for major reform to the Children's Court. At the time, magistrates in the Children's Court did not typically possess any formal training or experience in children and young people's affairs (Seymour, 1988b). One proposed change was the introduction of magistrates who had specialist knowledge of juvenile offenders and who could show greater sympathy when considering youth offending behavior. Others had also expressed concern that the court system had had a 'net-widening' effect - while the court had succeeded in removing many juveniles from the police and higher courts, there were fears that it also facilitated the prosecution of an entirely new cohort of children who previously would not have appeared in court at all, such as those who committed a trivial offense. Finally, the courts were supposed to be provided with background information about children when hearing matters, and allow children to be released under supervision, but this did not routinely occur. To address this limitation, a formal system of probation was introduced, which included probation officers who were trained to deal with youth matters and undertake supervisory duties, provide background information about the youth to the court, and provide counsel to the judiciary. It was intended that these changes would introduce a greater measure of sympathy towards youth in the court system, and take advantage of available scientific knowledge of the developmental and familial factors that led to young people appearing in court (Seymour, 1988a).

\section{A WELFARE-BASED REFORM OF THE JUVENILE JUSTICE SYSTEM}

In subsequent decades further issues concerning the procedure and operation of the children's courts attracted critical attention. There was continuing debate over what minimum qualifications magistrates should possess in order to administer the court in accordance with the guiding principles of the child-saving philosophy. The philosophy itself was often considered problematic due to its imprecise articulation, and it was often interpreted by magistrates as the need to simply adopt a more paternal and understanding manner when dealing with juveniles (Seymour, 1988b). Significant differences in power and authority existed between the bench and the welfare authorities, with regard to issues such as the duration of custodial terms and whether these matters should be judicially determined or left to the discretion of those who administered court orders.

In the late 1960 s, there were calls to implement major changes to the existing juvenile justice system. Reform was considered necessary in order to respond effectively to the long delays (and the significant expense associated with delays) that occurred frequently in the court process. The court system attracted criticism for being ineffective because court hearings were typically conducted long after the crime was committed, and the relationship between criminal offense and its consequences was thought to be much less salient to the young offender due to this delay in processing. In addition, the system appeared to lack the means to handle less serious offenders, including first time offenders. In 1968, the South Australian Social Welfare Advisory Council (ASWAC) published a report recommending the implementation of Juvenile Aid Panels within the larger Juvenile Crime Prevention Scheme. The Scheme aimed to: (a) reduce the number of offenses committed by juveniles, in particular avoiding the prosecution of children for minor offenses; (b) encourage the reporting of offenses so as to ensure that juvenile offenders were detected and remedial action was taken as early as possible; and (c) ensure that first time offenders and their parents were warned about the possible consequences of the offenders' behavior without the necessity for Court action, except in more serious cases. The recommendations of the ASWAC report were a catalyst for the development of the Juvenile Courts Act 1971; legislation that would allow much greater flexibility in dealing with young people in the juvenile justice system.

The Juvenile Courts Act 1971; established Juvenile Aid Panels to deal with truants and those children that it termed 'uncontrollable'. Children who appeared before these panels would have no formal charges brought against them, no convictions would be recorded, and severe penalties would not generally be imposed. The Aid Panel had the discretion to deal with a matter directly or it could recommend that a matter be referred to a Children's Court. While the Juvenile Aid Panels appeared to uphold principles of the child-saving philosophy, in that it operated on the basis that youths should be spared from the full force of the adult law, advocates of the due process model of justice criticized the Aid Panels for being largely ineffectual in dealing with serious young offenders (Abraham, 1982). Additionally, there was concern that fewer cautions were being issued and more young people were brought into the justice system on the assumption 
that the Aid Panels would deal with them in some way. Dissatisfaction with this system of justice and its guiding legislation, eventually led to the Act being repealed by the Children's Protection and Young Offenders Act 1979.

\section{BACKGROUND TO THE CURRENT SYSTEM}

In 1991 a Parliamentary Select Committee was formed to respond to calls that the existing juvenile justice was inadequate. It was claimed that the penalties being handed down by the Children's Court were too lenient or lacking in relevance and, in some cases, not properly enforced due to the lack of human resources (Abraham, 1982). The Committee was also concerned with the ongoing debate over whether the system was dealing effectively with the serious offender and/or the long-term recidivist. The Justice and Consumer Affairs Committee (1988) concluded that the various discretionary mechanisms in place at the time had led to a number of 'net-widening' effects, specifically with regard to the growing number of Aboriginal juveniles entering the legal system (Gale \& Wundersitz, 1989). The Committee also identified numerous other problems, including: (a) long delays in processing youth offenders (with some offenders reoffending before their first appearance within the system); (b) the non-participatory role of the offender and the threat of marginalization by the presence of lawyers, social workers and other professionals; (c) the exclusion of the victim from the process; and (d) the failure to include the young person's parents in the decision-making process. The police also felt limited in their position as the first point-of-contact with youth offenders, as they lacked any alternative formal means of dealing with youth crime. Most matters dealt with by police, irrespective of how minor, were being dealt with by arrest and charge (Seymour, 1988a).

To address these limitations, the Parliamentary Select Committee reviewed the methods and success rates of juvenile justice systems in other jurisdictions, including international jurisdictions. The Committee identified the New Zealand juvenile justice system, and its innovative concept of family group conferences, as an appropriate system for potential emulation in South Australia. Following a three year period of research and discussion, the Select Committee tabled its first Interim Report in November 1992, which called for broad changes to be made to both the philosophy and structure of the juvenile justice system. Its recommendations formed the basis for three new pieces of legislation: the Young Offenders Act, the Youth Court Act and the Child Protection Act. These bills were passed in December 1993, and replaced the Children's Protection and Young Offenders Act 1979.

\section{ESTABLISHMENT OF THE SOUTH AUSTRALIAN YOUTH COURT}

Under the Youth Court Act 1993, the Young Offenders Act 1993, and the Children's Protection Act 1993, the existing Children's Court was abolished and the Youth Court was founded. Within the youth court system, juvenile justice and care and protection matters were defined and treated as distinctly separate matters. With regard to juvenile justice, these principles included: (a) ensuring that young people were held accountable for their behavior and experienced immediate and relevant consequences for their criminal acts; (b) increasing both the severity and range of penalties available at all levels of the system; (c) enhancing the role of the police in the juvenile justice system; (d) empowering families to play a greater role and to take more responsibility for their children's behavior; and (e) protect the rights of victims to restitution and compensation and allow victims, where appropriate, to confront the young offenders and make them aware of the harm which they had caused.

The Youth Court Act 1993 abolished Screening Panels and Children's Aid Panels, and introduced a two-tiered system of pre-court diversion, consisting of police cautioning and family conferencing, which were intended to deal with minor offenses. These diversionary approaches to juvenile justice were based partly on Braithwaite's (1989) notion of 're-integrative shaming', which is a process of negotiation and reparation whereby the offender is shamed, but not stigmatized, for the offense that has occurred. Responsibility for administration of the new system rested with three key agencies: the South Australian Police, the Courts Administration Authority, and the Family and Youth Services Division of the Department of Human Services (now known as the Department for Families and Communities).

\section{OPERATION OF THE CURRENT YOUTH JUSTICE SYSTEM}

The Young Offenders Act 1993 introduced a multi-tiered system of pre-court diversion designed to deal with minor offenses (Moore \& Wilkinson, 1994). This system applies to youths who at the time of the alleged offense were aged 10 to 17 years inclusive, and provides four processing options: (a) informal caution; (b) formal police caution; (c) family conferencing; and (d) a court appearance. Recent court statistics show that there were 6,862 youth apprehension reports lodged by police in 2007 (Office of Crime and Statistics Research, 2010). Of these, there were 2,086 referrals to a caution, which resulted in 2,064 formal cautions being administered. An additional 1,584 cases were finalized by the Family Conference Team and the Youth Court itself finalized 2,277 cases. The decision regarding the type of action taken against a youth (i.e., whether he or she will receive a caution or a family conference, or be directed to the Youth Court) rests primarily with the police and with specialist Community Programs Unit Managers. However, the Youth Court does retain some gate-keeping powers - a magistrate may overturn any court referral decision made by a Community Programs Unit Manager and send the matter back for either a caution or conference. The court may also exercise a referral role in the case of those youths who have been arrested but not granted police bail.

If a youth commits an offense which, according to police guidelines, could be classed as 'trivial', an operational police officer may administer an informal caution. These are given on the spot and are not formally recorded. Alternatively, a police officer may decide that an offense warrants a formal caution. This is usually delivered either by a cautioning officer or by a specially appointed Youth and Community Officer in the presence of either a parent or guardian, or an adult closely involved with the youth. As part of a formal caution, a cautioning officer has the power to require the young person to enter into a formal undertaking, such as community service or paid compensation. 
Offenses that are considered too serious for a caution may be referred to a family conference. A family conference may only be scheduled if the youth admits to the commission of the offense. For this reason, the family conference system has been criticized for its potential to pressure young offenders to confess to an alleged crime (Warner, 1994; Wundersitz, 1996). The young offender, the coordinator, and a police representative are statutorily required to be present at the conference. Other participants may include the offender's parents, family or friends, the victim and his or her supporters and any other person who it is considered could make a contribution to the conference. The aim of the conference is to give all participants the opportunity to discuss the offense, to identify the harm that has been caused, and to decide on an appropriate outcome. Outcomes include: (a) a formal caution in writing, signed by the youth; (b) an undertaking to pay compensation; (c) an undertaking to carry out community service, to a maximum of 300 hours; and (d) an apology to the victim.

If a youth commits a serious offense, is a repeat offender, or fails to comply with a family conference undertaking, then he or she may be formally charged and sent to the Youth Court. However, even after a charge has been laid, the Youth Court may still refer the matter for a police caution or a family conference (once the youth's guilt has been established) if the court believes this approach to be more appropriate. The Court can remand a young person in custody or sentence a young person to Detention, requiring residence in a secure young offender training centre for a specified period of time, if no other order is appropriate. As an alternative to detention, the Young Offenders Act 1993 allows the court to order a period of home detention, to be served either as a standalone option or as a joint secure care/home detention order.

\section{RECENT AMENDMENTS TO JUVENILE JUSTICE LEGISLATION}

Since 1993, there have been some amendments to juvenile justice legislation that have had implications for how the Youth Court operates. Perhaps the most significant of these amendments is the Statutes Amendment (Young Offenders) Act 2007. This amendment makes provisions for specific responses to serious repeat offending by young people. In particular, the Act amended Section 2A of the Young Offenders Act 1993, which states that "if the sanctions are imposed by a court on a youth who is being dealt with as an adult (whether because the youth's conduct is part of a pattern of repeated illegal conduct or for some other reason), regard should be had to the deterrent effect any proposed sanction may have on other youths; and the balance to be achieved between: (a) the protection of the community; and (b) the need to rehabilitate the youth". In addition, Section $15 \mathrm{~A}$ of the Young Offenders Act is amended to grant authority to the court, in deciding whether a youth poses an appreciable risk to the safety of the community, whether to consider the following factors: (a) the gravity of the offense with which the youth is to be charged; (b) if the offense to be charged is part of a pattern of repeated offending by the youth; (c) the degree to which the youth has previously complied with (i) any undertaking entered into by, or requirement or obligation imposed on, the youth under this Act (ii) with any bail agreement under the Bail Act 1985; and (d) the behavior of the youth while so detained; and any rehabilitation of the youth while so detained.

The introduction of the Statutes Amendment (Recidivist Young Offenders and Youth Parole Board) Act has not been without criticism. For instance, the Children and the Law Committee of the Law Society (June, 2009) argue that, by categorizing certain young people as 'recidivist young offenders' and imposing a different set of procedural rules with regard to applying for conditional release, such youths may be further marginalized and experience greater difficulty in reintegrating with the community.

\section{SUMMARY}

This brief history of the South Australian Youth Court highlights a long-standing recognition that the courts should view children and adolescents as distinctly different from adults and balance the competing needs of: (a) sparing vulnerable individuals from the potential harms and stigmatizing effects of the court process; while (b) ensuring that the community is adequately protected from more serious young offenders. It may be observed that the difficulties arising from managing the welfare needs of young people, while ensuring the effective administration of punishment and deterrence, still persist in the contemporary youth court system and are not always easily resolved.

\section{Insights from Youth Court Judicial Officers}

As part of an ongoing Australian Research Councilfunded research project to be fully published in 2011, a series of interviews with South Australian Youth Court judicial officers were conducted to explore current challenges in areas of juvenile justice, including those related to the Youth Courts' basic aims and philosophy, current procedure and operation, guiding legislation, and overall effectiveness as a system of justice. Participants included two Judges and four magistrates working in the metropolitan context, two regional magistrates, and a former Youth Court Judge. A number of key elements of the Youth Court were examined to obtain a broad appraisal of its functioning, its adherence to guiding principles and the extent to which it had overcome or addressed concerns raised in previous reviews. Each interview was conducted in-person, and followed a semistructured format containing 20 open-ended questions, with added flexibility to accommodate each interviewee's specialized knowledge or particular interests or further comments on the Youth Court. Each interview took approximately 60 minutes to complete. All interviews were digitally recorded, with permission, and then transcribed. In line with ethical guidelines, participants were informed that they would not be personally identified in the reporting of results. The key points of each interview were extracted and summarized for further critical discussion.

\section{Guiding Philosophy of the Youth Court}

Respondents were asked to provide their personal view of the key aims and principles underlying the youth court system in South Australia. All respondents made reference to, and endorsed, the statutory principles of the Youth Court Act 1993, and acknowledged that the court was influenced by particular societal values concerning the need to respond appropriately to young offenders. As one respondent stated. 
- I think that civilized societies deal with their young in a very different way to adults.

\section{CORRECTION OF THE YOUNG PERSON}

Of primary concern to all respondents was that the court operated in such a way as to 'correct' young people's criminal offending. The process of correction was twofold: to impose some form of legally binding constraint (which may or may not involve punishment) on the young person to minimize future offending, and to encourage positive behavioral change. Respondents viewed the court as acting primarily in the interests of the child, whom by definition does not have a complete understanding of how their own actions may affect them.

- The primary purpose for me is correction. For young people, the focus is really to ensure change because you're dealing with people who are not mature by definition.

- You have to have the interests of the child as the paramount consideration. I think the objects and statutory policies of the Young Offenders Act is set up pretty clearly - to make them responsible members of the community and understand the effect of their actions.

- The overriding thing is to act in their best interests and do what's best for them. You have to weigh up your sentence with what would fit best with them. The level of support they've got at home obviously affects the nature of your penalty.

\section{BALANCING WELFARE WITH PUNISHMENT}

The need to balance the provision of welfare and the administration of punishment was viewed by respondents as paramount. Respondents acknowledged that, for many young people, their offending behavior may not be addressed effectively by punishment alone, and therefore a more sympathetic approach was considered to be necessary, especially for less serious offenders. The Youth Court, in this sense, was viewed as serving a significant welfare role in the lives of many young offenders.

- [With regard to welfare and punishment] I think that there's a degree of emphasizing of both that occurs in practice. The main objective is to get these kids through these troublesome, turbulent years of adolescence and late primary school. Crack them and nudge them into forming views and holding values which allow them to be proper citizens within our society.

- My understanding is we run in this state a mixed welfare and justice model, under the Young Offenders Act. I think having a balance of the two is the appropriate way to go.

\section{YOUNG PEOPLE AS DISTINCT FROM ADULTS}

Respondents viewed young people as a special population defined by specific psychological capabilities and vulnerabilities. It was explained that the Youth Court was intended to be sensitive to the unique attributes of young people in shaping its response to offending behavior. Generally, severe penalties were viewed by judicial officers as being counter-productive to the overarching goal of correcting behavior.
- Young people are still developing. They've not fully matured. Their outlook and view of life is not fully formed. They are also dependent upon adults for their nurturing and sustenance. The imposition of extreme punishments on young people in their formative years is considered by society to be harmful to a forming person.

- The Youth Court is very different from the adult court. It's not as adversarial. The prosecutors are reasonable. They're keen for matters to be diverted and I think they are keen to do what is best for the kids.

\section{Strengths of the Youth Court}

Respondents were asked to reflect on what they considered to be the main advantages of having a specialist court for children in South Australia, and to identify those features of the current model of justice that appeared to be effective in dealing with young offenders.

\section{AUTONOMY AND INDEPENDENCE}

Respondents identified the independent legal status of the Youth Court as affording significant advantages to its work in protecting young people. There was broad consensus among respondents that, while the court serves an important welfare function for many young people, the court itself operates and should continue to operate separately from the broader welfare system in the state. As one respondent commented, the removal of government service providers from the bench of the Youth Court in the 1990s was a positive step in ensuring the court's operation was not unduly influenced by the competing interests of other organizational bodies.

- A court is always a court. It's a separate arm of government. It has an independent judicial function that is independent of the system - and by that I mean the system that services or offers maintenance or care to youths. When the youth appears in court, I think it is a mistake if the court is regarded simply as an extension of the social workers' system. If it does that, it loses its absolute core value and that is independence, because sometimes the youth needs protection from the system.

\section{RAPID RESPONSE TO YOUTH OFFENDING}

All respondents noted that the most significant strength of the Youth Court was its ability to respond to young offending within a relatively short time-frame. A rapid response was explained as being fundamental in dealing with young offenders, and perhaps even more important than the nature of the response. Because young people often have difficulty in relating their behavior to the consequences of the behavior it was argued that any delay in responding, irrespective of the actual response, increased the risk of that response being ineffectual. One respondent further noted that the need to act quickly was compounded by the fact that young people often commit offenses in close succession to each other.

- I've got an absolute obsession about how quickly we turn things over. I'd be surprised if there was a jurisdiction that would be up with us in that regard.

- Young people do not respond well to justice that is delayed. One day is a long time in the life of a 13 year old. To delay finalizing matters for six or twelve months like 
it occurs in the adult court, you may as well forget about it. There's no nexus between what they've done and what happens to them. A lot of them can probably hardly remember.

\section{FOCUS ON THE INDIVIDUAL}

Respondents highlighted that the youth court system, as stated within its statutory principles, places an emphasis on tailoring its judicial response to the individual rather than adhering to a model of justice that is based on general deterrence. In this way, the court may spend a great deal of time gathering the necessary background information about a given individual and his or her criminogenic needs so that it is well-positioned to recommend effective methods of rehabilitation.

- Because of the focus in the Act, we're running a much more intensive aim at the particular individual. We take into account personal deterrence but we don't take into account general deterrence. We're backed up by a good amount of supports that are available in terms of psychological and psychiatric and social background reports.

\section{DIVERSIONARY APPROACHES}

Respondents indicated that the Youth Court was wellserved by a wide range of diversionary options for dealing with young offenders, although it was noted that the range of available options was often limited outside the metropolitan area. In particular, the family conferencing system was reported to be a highly effective diversionary system, which had garnered positive feedback from both offenders and prosecution. In $2007,1,584$ referrals were finalized by the family conference team, and for the majority of these referrals an agreement was reached (Office of Crime and Statistics Research, 2010). According to respondents, feedback from those victims who attended the conference was also quite positive and, in some cases, relaying the consequences of the offense back to the young offender helped to build remorse for their offending behavior.

- What a sensible, humane idea it is to have a diversion program. There are quite a number of young people who get into difficulties at least once in their life and to actually put them through a very heavy experience would just be a waste of the community's resources and really often quite harmful.

- I think one of the strengths of our jurisdiction is our ability to divert matters. The police have that power to divert before it even comes to court. But often, if it's a relatively minor offense or a first offense, we have the ability to divert to either a formal caution or a family conference. That's great, because it's a relatively small percentage of people who keep coming back, a lot of them we don't see again.

\section{Challenges Facing The Youth Court}

Respondents were asked to consider the difficulties that the Youth Court routinely encounters in its role of administering juvenile justice. In addition, the judicial officers were asked to indicate ways in which the overall effectiveness of the current youth court system could be assessed objectively. A number of respondents highlighted from the outset that the availability of resources to the Youth Court could be improved, but it was added that lack of resources remained an issue throughout the wider South Australian courts system.

\section{RECIDIVISM}

One way of evaluating the Youth Court's ability to 'correct' juvenile offending is to examine whether young people who have entered the court system go on to commit further offenses. Some evidence suggests that about 4 out of 5 young people on supervised orders will reoffend and have future contact with adult corrections system, with half of them having served at least one term of imprisonment (Lynch, Buckman \& Krenske, 2003). In our study, several respondents indicated that the rates of recidivism provide a useful indicator of how well the Youth Court is operating. However, it was cautioned that recidivism rates could also be potentially misleading if not correctly presented, or if factors such as type of offense were not properly accounted for. Some judicial officers noted that some offenders engaged in repeat offending behavior until their first appearance in the Youth Court, and this was not necessarily indicative that the diversionary approaches were ineffective. Other respondents expressed a measure of uncertainty as to the optimal method for evaluating the effectiveness of the Youth Court but noted that it was important that the court was subjected to regular evaluation.

- I would say do not look at recidivism per se but look at individuals that have gone through the Youth Court and have eventually stopped offending. That is, for a period for six or 12 months there's been no further offending.

- My idea of a bigger picture is that if an offender came back three times in a row versus I didn't see him for six months. That's not a very big picture but where is the absolutely objective assessment of what we are doing is actually working?

\section{JUDICIAL OFFICER TRAINING}

The ability of the Youth Court to offer a specialist service that is sensitive to the needs of young people and their circumstances may be influenced by the level of training that judicial officers receive. Respondents were therefore asked about the qualifications and/or relevant experience of judicial officers and to what extent some form of training or further education (e.g., in areas of child development, youth mental health issues, etc.) may help them to respond to the needs of young offenders. Respondents indicated that judicial officers were selected on their basis of their ideological suitability as well as their experience in the legal profession. While judicial officers did not receive any additional formal training in specialist areas of knowledge, it was noted that they routinely engaged in professional development activities - either by sourcing relevant materials or attending conferences. Additionally, the judicial officers reported that the expert opinions expressed within court evidence helped them to gain a fuller understanding of each young offender. One respondent noted that, while judicial officers would be generally wellserved by expanding their specialist knowledge, very few individuals or organizations would be able to implement a structured system of training for judicial officers because it may threaten the courts' independence and objectivity. 
- The judicial staff that are picked to go there are ideologically suited for the work.

- One of the problems of judicial training is the risk that it'll be taken over by someone with a barrow to push. And there are always people trying to push barrows at us. I've personally found the most useful training was tracking down people I knew who had worked in the juvenile court system and then sitting down with them for a few days.

\section{CHANGING NATURE OF THE YOUNG OFFENDER}

The effectiveness of a specialist court for children may be judged according to its ability to adapt and respond to the changing needs of young offenders. According to the respondents, a significant problem faced by the South Australian Youth Court was the increasing complexity of young offenders. It was noted by respondents, some of whom reported over twenty years of experience working in some legal capacity with young offenders, that the modern profile of the young offender was characterized by greater problems associated with substance use, mental health issues or psychological disorders, family dysfunction, and disengagement from education. It was reported that these issues were generally more pronounced among Indigenous peoples. These are complex issues that face many young offenders, and the need to meet complex and multiple needs was reported to be steadily placing a greater burden on the juvenile justice system.

- I think there're significantly more mental health issues, since I've been here. That's very much on the increase. We're also going through a period of Foetal Alcohol Syndrome children.

\section{DIFFICULTIES IN THE REGIONAL CONTEXT}

South Australia is a geographically large and sparsely populated state of Australia. Specialist courts for young people may vary according to regional context, with each presenting unique problems for effective administration of justice. Several limitations of the juvenile justice system in remote and regional parts of South Australia were identified by respondents. In addition to the difficulties associated with fewer available services and resources in remote areas (such as the Anangu Pitjantjatjara Yankunytjatjara lands) as compared to the metropolitan context, which negatively affects all aspects of the court's administration, respondents highlighted the problem of consistency due to the rotating schedules of magistrates working in the regional context. The workloads of regional magistrates were also reported as being considerably higher than their metropolitan counterparts, given the higher number of cases each year, as well as the associated issues of limited resources, transport needs, and fewer supporting services. One respondent stated that a regional magistrate's workload was generally six days per week, as compared to five days per week for other magistrates.

- In a rural environment, it is pretty pot luck who the magistrate is that pops up and want to do it. The youth get what they get. So there obviously isn't the same consistency as if the Youth Court magistrates here were doing all the work.
- I think a lot of the services aren't available, for example, home detention, bail, you can't get in country areas. For example, the diversion court, it's only done in Adelaide so if people are from the country...there's an awful lot of things that can't be accessed.

- The problems are huge and the lack of support for Aboriginal people trying to do things is also huge. The funding streams are inadequate.

\section{GENERAL CONCLUSION}

This brief overview of the history, role, and function of the South Australian Youth Court in relation to juvenile justice matters, when set alongside the perspectives of contemporary judicial officers, raises a number of issues that are relevant to the development of children's courts in other jurisdictions, as well as potentially to other types of specialist court. The interview data highlighted that the Youth Court has a number of strengths as a specialist court for young people, including its status as an independent and autonomous judicial body, and its ability to offer a rapid response to juvenile offending and a range of diversionary options. Judicial officers viewed these key attributes as fundamentally important to the court's main philosophy of 'correcting' - rather than simply 'punishing' - young people's offending behavior. However, the interviewees acknowledged that the Youth Court also faces a number of challenges. These included difficulties in addressing the increasingly complex needs of young offenders, as well as providing effective service delivery with limited resources, particularly in regional courts. The judicial officers also noted that specialist knowledge of young people was highly desirable as an adjunct to their legal training, but that such knowledge was usually self-taught over time rather than delivered through a formalized system of training. This feedback demonstrates that, despite its stated philosophy based on correcting young people, the court sometimes falls short of realizing this goal for all young people due to limited available services and supports. Additionally, there would appear to be a need for further critical evaluation of the Youth's Court's relative success in meeting its general aim of reducing juvenile criminal behavior.

Most notably, the history of the Youth Court highlights the way in which the role and purpose of specialist courts can sometimes be poorly defined, and is susceptible to political changes. It is reminiscent of Petrila's (2003) critique of drug courts in the United States, and how these have been driven more by political agendas than by careful consideration of the theoretical and empirical evidence supporting their effectiveness. Petrila quotes a US judge as observing that the drug court has been embraced as a panacea without asking, let alone resolving, even the most basic of questions: What is the purpose of drug courts? Do drug courts work? Are the costs of drug courts, including costs in deindividualized justice, worth their benefit? Should the sentencing philosophy of a single drug court judge or group of drug court judges be institutionalized? Although the South Australian Youth Court has a long history of providing diversionary services and programs that are consistent with a 'child-saving' philosophy (see Wundersitz, 2007), the ways in which the best interests of the child (see Coppins, Casey, \& Campbell, this issue) have been defined and operational- 
ized have changed over time. In recent times, this philosophy has been influenced by the introduction of legislation that gives primacy to community safety, with young people increasingly being given more personal responsibility for their behavior (see Casey, this issue). It would seem from these interviews that the judiciary strongly support the idea that a balance should be struck between welfare and justice approaches and that the primary focus of the court should be on providing both positive treatment and criminal procedural justice. Both Feld (1997) and Scott and Grisso (1997) have argued that challenges to the way in which children's courts have developed are fair because, in their view, the courts have too often sought to simply excuse delinquency on account of the offender's youthfulness. While such critiques highlight the need to be clear about how developmental factors impact upon matters of criminal responsibility, the views reported in this paper underscore how programs and interventions need to strike a balance between managing the risk of further offenses occurring and supporting the healthy development of young people into adulthood. These considerations will depend upon the articulation of models of personal and criminal responsibility that can be measured and consistently applied. This will also involve court disposal being clearly based on the relationship between each characteristic (e.g., substance use, mental impairment) and risk of re-offending to determine the appropriate disposal. Such an approach clearly requires specialist professional knowledge and forensic training, as well as expertise in the behavioral sciences. Finally, and in line with Petrila's (2003) comments, there is clearly a need to conduct rigorous and controlled evaluations of the effects and outcomes of different types of court. As one respondent in our study commented:

- The challenge is getting your head up and looking at the big picture. We spend an awful lot of money on magistrates and judges, an awful lot on legal expertise, specialist buildings, and people supporting it. Does this system actually work? And is there another system? I think that's the challenge. Is this whole system working?

\section{ACKNOWLEDGEMENT}

This research was supported by the ARC and we are grateful to the Law Society for acting as a reference group for the research. The views expressed in this paper do not necessarily reflect those of either agency.

\section{REFERENCES}

Abraham, W. J. (1982). Recent changes in the South Australian system of juvenile justice. Unpublished Law thesis.

Andrews, D. A., \& Bonta, J. (2010). Rehabilitating criminal justice policy and practice. Psychology, Public Policy, and Law, 16, 39-55.

Berman, G., \& Feinblatt, J. (2005). Good Courts: The Case for ProblemSolving Justice. New York: The New Press.
Braithwaite, J. (1989). Crime, shame, \& reintegration. Cambridge: Cambridge University Press

Dickey, B. (1987). No charity there: A short history of social welfare in Australia. Sydney, NSW: Allen \& Unwin.

Feld, B. C. (1998). Abolish the Juvenile Court: Youthfulness, Criminal Responsibility, and Sentencing Policy. The Journal of Criminal Law \& Criminology, 88, 68-136.

Gale, F., \& Wundersitz, J. (1989). The operation of hidden prejudice in precourt procedures: The case of Australian Aboriginal youth. Australian and New Zealand Journal of Criminology, 22, 1-21.

Lynch, M., Buckman, J., \& Krenske, L. (2003). Youth justice: criminal trajectories. Trends and issues in crime and criminal justice no. 265. Canberra: Institute of Criminology.

Moore, T. \& Wilkinson, T. (1994). Youth Court: A guide to the law and practice. London: Longman Publishing.

Office of Crime and Statistics Research. (2010). Crime and Justice in South Australia; Juvenile Justice. Report prepared for the South Australian Attorney-General's Department.

Payne, J. (2006) Specialty courts: current issues and future prospects Trends and Issues in Crime and Criminal Justice. AIC No. 317, June 2006.

Petrila, J. (2003). An introduction to special jurisdiction courts. International Journal of Law and Psychiatry, 26, 3-12.

Polk, K. (2003). Juvenile Diversion in Australia: A National Review. Paper presented at Juvenile Justice: From Lessons of the Past to a Road Map for the Future Conference. Australian Institute of Criminology. 1-2 December 2003. http://www.aic.gov.au/conferenc es/2003-juvenile/ polk.html.

Seymour, J. (1988a). Dealing with young offenders. Sydney, NSW: The Law Book Company.

Seymour, J. (1988b). Juvenile justice in South Australia. Sydney, NSW: The Law Book Company.

Scott, E., \& Grisso, T. (1997). The evolution of adolescence: A developmental perspective on juvenile justice reform. Journal of Criminal Law and Criminology, 88, 137-189.

Select Committee on the Juvenile Justice System. (1992, November). Interim Report of the Select Committee on the Juvenile Justice System. Adelaide, SA: Government Printer.

The Children and the Law Committee of the Law Society of South Australia. (June, 2009). A response to the introduction of the Statutes Amendment (Recidivist Young Offenders and Youth Parole Board) Bill 2009. Retrieved online from: http://www.lawsocietysa.asn.au/ submissions/090616Statutes_Amendment_Recidivist_Young_Offender s_and_Youth_Parole_Board_Bill_2009.pdf

Ward, T., Day, A., \& Casey, S. (2006). Offender rehabilitation down under. Journal of Offender Rehabilitation, 43, 73-83.

Warner, K. (1994). Family group conferences and the rights of the offender. In C. Alder \& J. Wundersitz (Eds). Family Conferencing and Juvenile Justice: The Way Forward or Misplaced Optimism? Australian Institute of Criminology, Canberra.

Wexler, D. (2000). Therapeutic Jurisprudence: an overview. International Network on Therapeutic Jurisprudence. Retrieved online from: http://www.law.arizona.edu/depts/upr-intj/

Winick, B. (2003). The Judge's role in encouraging motivation for change. in B. Winick and D. Wexler (eds), Judging in a Therapeutic Key: therapeutic jurisprudence and the courts (pp.181-188). Durham: Carolina Academic Press.

Wundersitz, J., (1989) The Net Widening Effect of Aid Panels and Screening Systems in the South Australian Juvenile Justice System, Department of Community Welfare, South Australia.

Wundersitz, J. (1996). The South Australian Juvenile Justice System: A Review of its Operation. Office of Crime Statistics, SA AttorneyGeneral's Department, Adelaide.

Wundersitz, J. (2007). Criminal justice responses to drug and drug-related offending: Are they working? Technical and Background Paper No. 25. Canberra: Australian Institute of Criminology. 